\title{
Dialysis Bone Disease in Childhood: Treatment with 25-Hydroxycholecalciferol
}

\author{
JEAN-CLAUDE LUCIANI (23), PIERRE-J. MEUNIER, AND ROBERT DUMAS \\ Clinique de Pédiatrie, Hopital Saint-Charles, Montpellier, and Laboratoire de Recherches sur IHistodınamique \\ Osseuse, Universite Claude Bernard, Lyon, France
}

\begin{abstract}
Summary
The effect of 8 months of administration of moderate doses of 25-hydroxycholecalciferol ( $25 \mathrm{OH}$ D3) on radiologic, biologic, and bone histologic changes was assessed in five children on chronic hemodialysis. Osteomalacia, defined by an increase in the thickness index of the osteoid seams and decrease of the calcification rate, was present on the initial bone biopsy of only one patient and improved with the treatment. Secondary hyperparathyroidism and its prints on bone tissue, noted in all five children, did not improve in the absence of adequate serum phosphorus control. Furthermore, cancellous bone volume diminished in two patients with the administration of $25 \mathrm{OH}$ D3. This activity of the drug could be related to its inhibitory effect of osteoblastic apposition as demonstrated by the decrease in the calcification rates, while the thickness index of the osteoid seams remains normal.

Despite the small number of patients studied, these results suggest the importance of limiting the prescription of $25 \mathrm{OH} \mathrm{D3}$ to children suffering from renal osteodystrophy only after having assessed unequivocally an osteomalacic component by histodynamical criteria. Secondary hyperparathyroidism appears not to be improved with moderate doses of $25 \mathrm{OH} \mathrm{D3}$ in the absence of adequate serum phosphorus control.
\end{abstract}

\section{Speculation}

Treatment with $25 \mathrm{OH} \mathrm{D3}$ may be justified for the treatment of chronic hemodialyzed children with definite osteomalacia as a component of their renal osteodystrophy. Secondary hyperparathyroidism appears not to be improved with moderate doses of 25 OH D3 in the absence of adequate serum phosphorus control.

Only a few studies have been performed on the treatment of renal osteodystrophy with vitamin $\mathrm{D}$ metabolites in chronic hemodialyzed children $(17,21)$ and none has included a dynamic histologic analysis based on tetracycline double labeling. The effect of 8 months administration of moderate doses of $25 \mathrm{OH} \mathrm{D3}$ on radiologic, biologic, and bone histologic changes was assessed in five children on chronic hemodialysis.

\section{PATIENTS AND PROCEDURE}

Five children 11- to 19-yr-old, were included in this study. All presented with renal osteodystrophy as estimated by clinical and radiologic data, serum immunoreactive parathyroid hormone (iPTH) levels and histologic criteria (Tables 1-3). Details of these findings have been given elsewhere $(8,12)$. They were dialyzed for $5 \mathrm{hr}$ three times a week using a calcium dialysate of 1.75 mmole/liter. Before treatment with $25 \mathrm{OH} \mathrm{D3,} \mathrm{each} \mathrm{child} \mathrm{was}$ given daily 25 mmole $(1 \mathrm{~g})$ of calcium, 125 nmole (2000 IU) of vitamin D2, and $7.5-11.5$ mmole $(600-900 \mathrm{mg})$ of aluminium hydroxide.

The synthetic 25 OH D3 (Laboratoires Roussel, Paris, France) was given orally, once a day during 8 months. Seventy-five nmole $(30 \mu \mathrm{g})$ of $25 \mathrm{OH} \mathrm{D} 3$ were administered, daily during the first 3 months of the study; then, the dose was increased to 125 nmole $(50 \mu \mathrm{g})$ daily during the next 5 months. During the study, calcium supplements and vitamin D2 were discontinued. The aluminium hydroxide was followed at the same dose. No patient was receiving anticonvulsivant drugs.

\section{METHODS}

PLASMA BIOCHEMISTRY

All blood samples were obtained immediately before dialysis. Total plasma calcium was measured by atomic spectrophotometry (Perkin Elmer). plasma phosphorus, and alkaline phosphatases (1) with autoanalyzer (Technicon. Daumont, France). Serum iPTH levels were measured by radioimmunoassay using a guineapig antibody (GP6) and identifying the carboxy terminal of PTH $(2,5)$. Serum 25 -hydroxy vitamin D (25 OHD) concentrations were measured using a radiocompetitive protein binding assay (18).

\section{RADIOLOGIC FVALUATION}

The subperiostal resorption was looked for on X-ray examinations of the phalanges and the skull. Osteomalacia was assessed on radiograms of the wrist and the tibiae and osteosclerosis on the third lumbar vertebra. Bone maturity was measured according to Greulich and Pyle (11).

\section{BONE HISTOMORPHOMETRY}

Bone tissue was obtained before and contralaterally 8 months after $25 \mathrm{OH}$ D3 therapy. Transfixing iliac bone biopsies were performed on patients with an $8 \mathrm{~mm}$ internal diameter trephine. after tetracycline double labeling, consisting of a dose of $15 \mathrm{mg}$ / $\mathrm{kg} /$ day of Declomycin given for 2 days and, after an interval of 12 days, repeated for 4 days. The biopsy site was situated about 2 $\mathrm{cm}$ below the top of the iliac crest and $2 \mathrm{~cm}$ behind the anterosuperior iliac spine.

The undecalcified bone samples were embedded in Bioplastic Ward's and 10 longitudinal nonconsecutive serial sections, $8 \mu \mathrm{m}$ thick, were cut with a microtome Jung $K$. Four sections were stained with Solochrome cyanin R, four with Goldner's stain and two with Toluidine blue. Four additional unstained sections, 20 $\mu \mathrm{m}$ thick, were used for the analysis of tetracycline labels, under fluorescent light.

The following parameters were measured: 1) Trabecular bone volume (T.B.V.) that represents the fraction of the cancellous bone volume occupied by bone matrix (\%). 2) Trabecular osteoclastic resorption surface (T.O.R.S.), that represents the percent of the total trabecular bone surface occupied by resorption sites (that notch the trabecular edges) (\%). We did not distinguish between "active" and "inactive" resorption surfaces, according to the presence or absence of osteoclasts in the Howship's lacunae. 3) Number of osteoclasts per $\mathrm{mm}^{2}$ of bone tissue (section) $\left(\mathrm{Ocl} / \mathrm{mm}^{2}\right) .4$ ) Trabecular osteoid volume (T.O.V.) that represents the percent of a given volume of the trabecular bone occupied by osteoid (\%). 5) 
Table 1. Clinical data

\begin{tabular}{|c|c|c|c|c|c|c|c|c|c|}
\hline \multicolumn{3}{|c|}{ Patients } & & \multicolumn{2}{|c|}{ Duration } & \multicolumn{2}{|c|}{ Height $(\mathrm{cm})$} & \multicolumn{2}{|c|}{ Bone age $(\mathrm{yr})$} \\
\hline \multirow[b]{2}{*}{$N$} & \multirow[b]{2}{*}{ Sex } & \multirow{2}{*}{$\begin{array}{l}\text { Age } \\
(\mathrm{yr})\end{array}$} & \multirow[b]{2}{*}{ Diagnosis } & \multirow{2}{*}{$\begin{array}{c}\text { Renal } \\
\text { failure } \\
(\mathrm{yr})\end{array}$} & \multirow{2}{*}{$\begin{array}{c}\text { Hemodialysis } \\
\text { (months) }\end{array}$} & \multicolumn{2}{|c|}{ treatment } & \multicolumn{2}{|c|}{ treatment } \\
\hline & & & & & & Pre & Post & Pre & Post \\
\hline 1 & $\mathrm{~F}$ & 13 & Renal hypoplasia & 11 & 44 & 119.5 & 122.5 & $7111 / 12$ & $8^{10 / 12}$ \\
\hline 2 & $\mathrm{~F}$ & 11 & $\begin{array}{l}\text { Membrano-proliferative glo- } \\
\text { merulonephritis }\end{array}$ & 4 & 40 & 120 & 123 & 7111112 & $8^{111 / 2}$ \\
\hline 3 & $\mathrm{~F}$ & 19 & Oligonephronic hypoplasia & 17 & 32 & 142.5 & 142.5 & & \\
\hline 4 & $\mathbf{M}$ & 18 & Uropathy & 3 & 28 & 165 & 165 & & \\
\hline 5 & M & 13 & $\begin{array}{l}\text { Membranous glomerulone- } \\
\text { phritis }\end{array}$ & 4 & 16 & 140.5 & 141 & $12^{\mathrm{k} / 12}$ & $12^{6 / 12}$ \\
\hline
\end{tabular}

Table 2. Biologic data before and after $25 \mathrm{OH}$ D3 therapy

\begin{tabular}{|c|c|c|c|c|c|}
\hline \multirow[b]{2}{*}{$\begin{array}{c}\text { Patients } \\
N\end{array}$} & \multicolumn{5}{|c|}{ Plasma } \\
\hline & $\begin{array}{c}\mathrm{Ca} \\
\text { (mmole/liter) }\end{array}$ & $\begin{array}{c}\mathbf{P} \\
\text { (mmole/liter) }\end{array}$ & $\begin{array}{c}\text { Alkaline } \\
\text { phosphatase } \\
(\mathrm{IU} / \mathrm{ml})\end{array}$ & $\begin{array}{c}\text { PTH } \\
(\mu \mathrm{lEq} / \mathrm{ml})\end{array}$ & $\begin{array}{c}25 \mathrm{OHD} \\
\text { (nmole/liter) }\end{array}$ \\
\hline 1 Control & 2.37 & 1.84 & 68 & 222 & 26 \\
\hline After $25 \mathrm{OH} \mathrm{D3}$ & 2.40 & 2.54 & 36 & 465 & 135 \\
\hline 2 Control & 2.12 & 3.06 & 72 & 325 & 39.50 \\
\hline After $25 \mathrm{OH} \mathrm{D3}$ & 2.55 & 2.29 & 25 & 340 & 250 \\
\hline 3 Control & 2.27 & 2.19 & 42 & 440 & 52.50 \\
\hline After $25 \mathrm{OH} \mathrm{D3}$ & 2.32 & 1.51 & 22 & 490 & 250 \\
\hline 4 Control & 2.65 & 2.70 & 22 & 185 & 26.50 \\
\hline After $25 \mathrm{OH} \mathrm{D3}$ & 2.67 & 3.25 & 35 & 270 & 250 \\
\hline 5 control & 2.62 & 2.64 & 25 & 76 & 54 \\
\hline After $25 \mathrm{OH} \mathrm{D} 3$ & 2.40 & 3.03 & 25 & 405 & 140 \\
\hline Normal range & $\begin{array}{l}2.07-2.62 \\
(n=13)\end{array}$ & $\begin{array}{c}0.96-1.77 \\
(n=13)\end{array}$ & $\begin{array}{c}9-35 \\
(n=13)\end{array}$ & $\begin{array}{c}0-50 \\
(n=35)\end{array}$ & $\begin{array}{l}12.0-61.5 \\
(n=39)\end{array}$ \\
\hline $\begin{array}{l}\text { Age range of the control } \\
\text { subjects }(y r)\end{array}$ & & & $10-15$ & Adults & $20-35$ \\
\hline
\end{tabular}

Trabecular osteoid surfaces (T.O.S.) that represents the percent of the total trabecular surfaces covered by osteoid (\%). 6) Thickness index of the osteoid seams (T.I.O.). This index is calculated by the ratio T.O.V./T.O.S. $\times 100.7$ ) Calcification rate (C.R.) was evaluated in cancellous bone by measuring the mean distance between the two fluorescent labels on each site of active calcification (10).

\section{RESULTS}

\section{CLINICAL AND RADIOLOGIC RESULTS}

The five children had no deformities, bone pain, or epiphysiolysis. Growth retardation was present in three cases (patients 13) (Table 1) and $25 \mathrm{OH} \mathrm{D3}$ had little effect on growth velocity that never exceeded $3 \mathrm{~cm} / \mathrm{yr}$. There were no extraosseous calcifications, except conjunctival calcifications that were revealed on slit lamp examination at the beginning of treatment in three children (patients 3-5) and were present at the end of the study in four cases (patients 1, 2, 4, 5). Subperiostal resorption was noted in four cases (patients 1-4) and osteosclerosis in two (patients 3, 4). No change of these radiologic signs was noted as an affect of the treatment. Classical radiologic signs of osteomalacia or rickets were never observed. Bone age increased by $1 \mathrm{yr}$ in two of the children during the study (patients 1,2 ).

\section{BIOLOGIC RESULTS (TABLE 2 AND FIGURE 1)}

Plasma calcium, phosphorus, and alkaline phosphatase were checked regularly every month and the results are given in Figure 1. Plasma calcium remained within the normal range during the treatment, except in one child who had transient hypercalcemia (patient 2). In this case, treatment was temporarily discontinued. Plasma phosphate levels were elevated in all cases despite aluminium hydroxide, and there was no consistent change in serum phosphorus concentrations after $25 \mathrm{OH} \mathrm{D3}$, except in patient 3 whose plasma levels returned to within the normal range after 6 months of treatment. Plasma alkaline phosphatase concentrations were initially elevated in three children (patients 1,2 , and 3 ) and returned gradually to within normal range. Plasma iPTH increased in the five children, but the variation of the mean level was not significant $(P<0.1)$. Circulating 25 OHD levels were all normal before the study and rose significantly $(P<0.001)$ in every case.

HISTOMORPHOMETRIC RESULTS (TABLE 3)

At the beginning of the study, all five children had histomorphometric abnormalities. The classical signs of hyperparathyroidism (increase of the trabecular osteoclastic resorption surfaces and of the number of osteoclasts per $\mathrm{mm}^{2}$ ) were seen to varying degrees in all five cases. With the treatment, hyperparathyroid signs did 
Table 3. Histometric data before and after $25 \mathrm{OH}$ D3 therapy

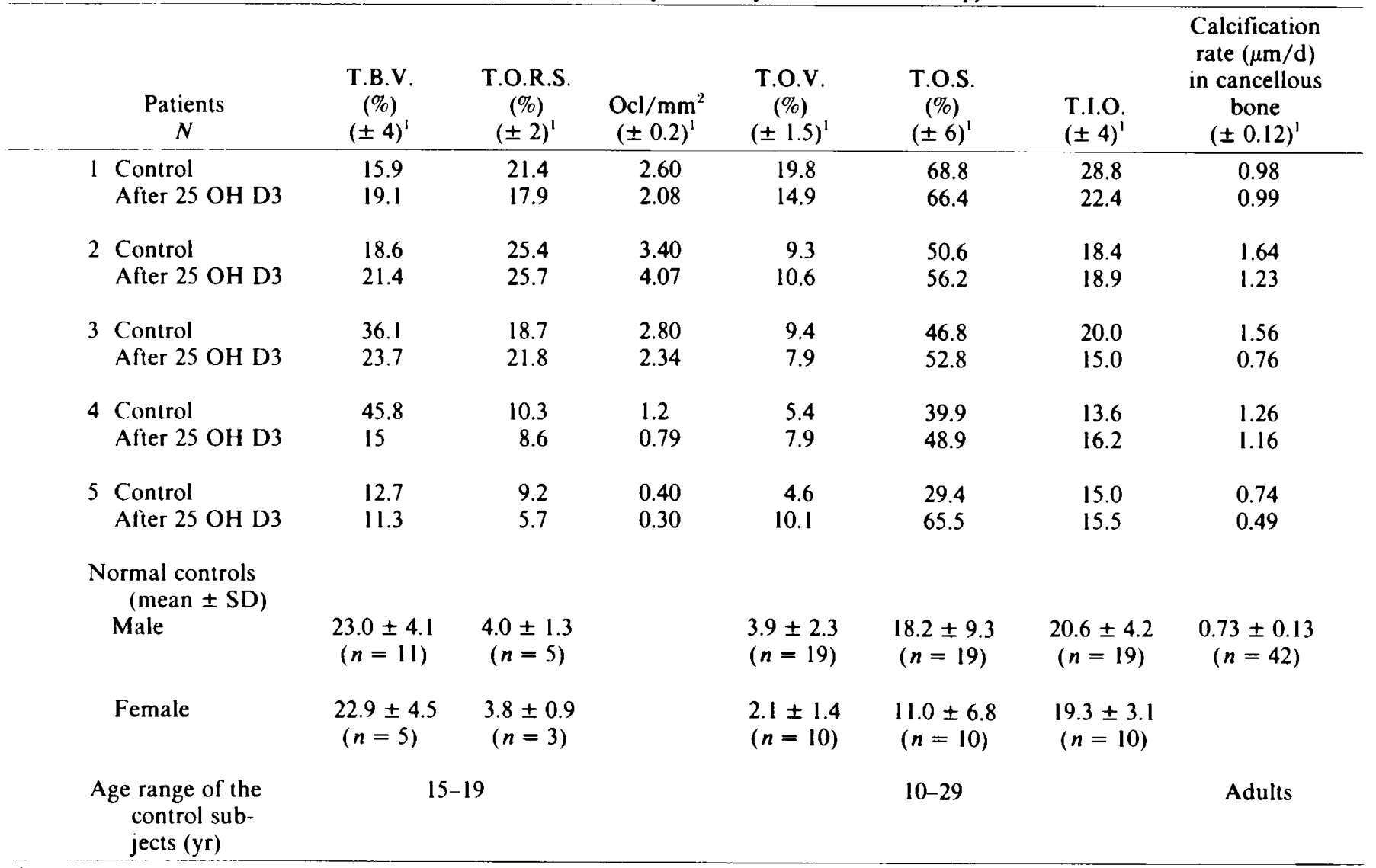

This $\mathrm{SD}$ is an approximation taking into account the intraobserver error and the sampling variation.

not change significantly. Osteomalacia, defined by an increase in the thickness index of the osteoid seams and decrease of the calcification rate (13), was present on the initial bone biopsy of only one patient (1) and improved with the treatment.

In the four other cases, the increase of the trabecular osteoid surfaces without modification of the calcification rate and of the thickness index, did not indicate osteomalacia, but only hyperparathyroidism, according to previous studies (13). Under the treatment, the trabecular osteoid surfaces increased in all these cases, while the calcification rate decreased. As the thickness index remained unchanged, the decrease in calcification rate was only due to a decrease in osteoblastic appositional rate, in other words, to a decrease in the rate of synthesis of new collagen by osteoblasts.

The trabecular bone volume was initially increased in two children (patients 3 and 4 ) and decreased in a third child (patient $5)$. Under the treatment, the trabecular bone volume diminished in the two patients with osteosclerosis. The surface of bone section occupied by woven bone decreased markedly under treatment. This decrease was assessed on qualitative criteria because the quantification of woven bone is imprecise.

\section{DISCUSSION}

Few studies have been made on the treatment of dialysis bone disease with 25 OH D3 $(9,19,21)$ and only one concerned children (21). Antirachitic effect with pharmacologic doses of $25 \mathrm{OH} \mathrm{D3}$ has been previously demonstrated in renal osteodystrophy $(3,7$, 9, 19,21). Moderate doses of this drug administered over a short period of time improved calcification front (7). It has been suggested that $25 \mathrm{OH}$ D3 in physiologic concentrations can have an effect on bone mineralization in chronic renal failure (6). Eight anephric patients have shown no histologic evidence of osteomalacia up to $6 \mathrm{yr}$ after bilateral nephrectomy (3). Eastwood et al. (6) noted a defect of mineralization only in patients with chronic renal failure in whom plasma 25 OHD levels were low. However, this result was not confirmed in another study (15). It seems possible that $25 \mathrm{OH} \mathrm{D3}$ is directly involved in active mineralization. The selective incorporation of tritiated $25 \mathrm{OH} \mathrm{D} 3$ in epiphyseal cartilage and bone growing rats has been reported (20).

Hypercalcemia may be seen during $25 \mathrm{OH} \mathrm{D} 3$ treatment. This disorder required, in a previous study, an interruption of the treatment and several injections of calcitonin; in one case, subtotal parathyroidectomy was performed (21).

The improvement of hyperparathyroidism is less evident. A drop in serum iPTH levels was absent in this study and insignificant in others $(7,9)$. Hyperphosphoremia prevents perhaps this decrease (9). A rise in phosphoremia has been previously reported during treatment with $25 \mathrm{OH} \mathrm{D} 3$ (9) or 1- $\alpha$-hydroxycholecalciferol $(9,16)$. It may be explained by an increase in the intestinal absorption of phosphate, demonstrated during treatment with 1 $\alpha$-hydroxycholecalciferol (16). In this study, secondary hyperparathyroidism and its prints on bone tissue, noted in all five children, did not improve in the absence of adequate serum phosphorus control. However, controversial results have been reported with a decrease in circulating iPTH (19) and in hyperparathyroidism bone lesions $(19,21)$. In these studies, plasma phosphorus levels were variable (21) or not reported (19). In addition, it is possible that, in these cases, the doses of $25 \mathrm{OH}$ D3 used might not have been large enough because serum 25 OHD levels failed to rise above 135-250 nmole/liter during the treatment.

Furthermore, cancellous bone volume diminished in two patients with the administration of $25 \mathrm{OH}$ D3. This was noted in a previous study (21). This activity of the drug could be related to its inhibitory effect of osteoblastic apposition. The inhibition of osteoblastic apposition is demonstrated in our cases by the decrease in the calcification rates, while the thickness index of the osteoid seams remains normal. This fact coincides with a marked decrease of the areas occupied by woven bone. Woven bone is 

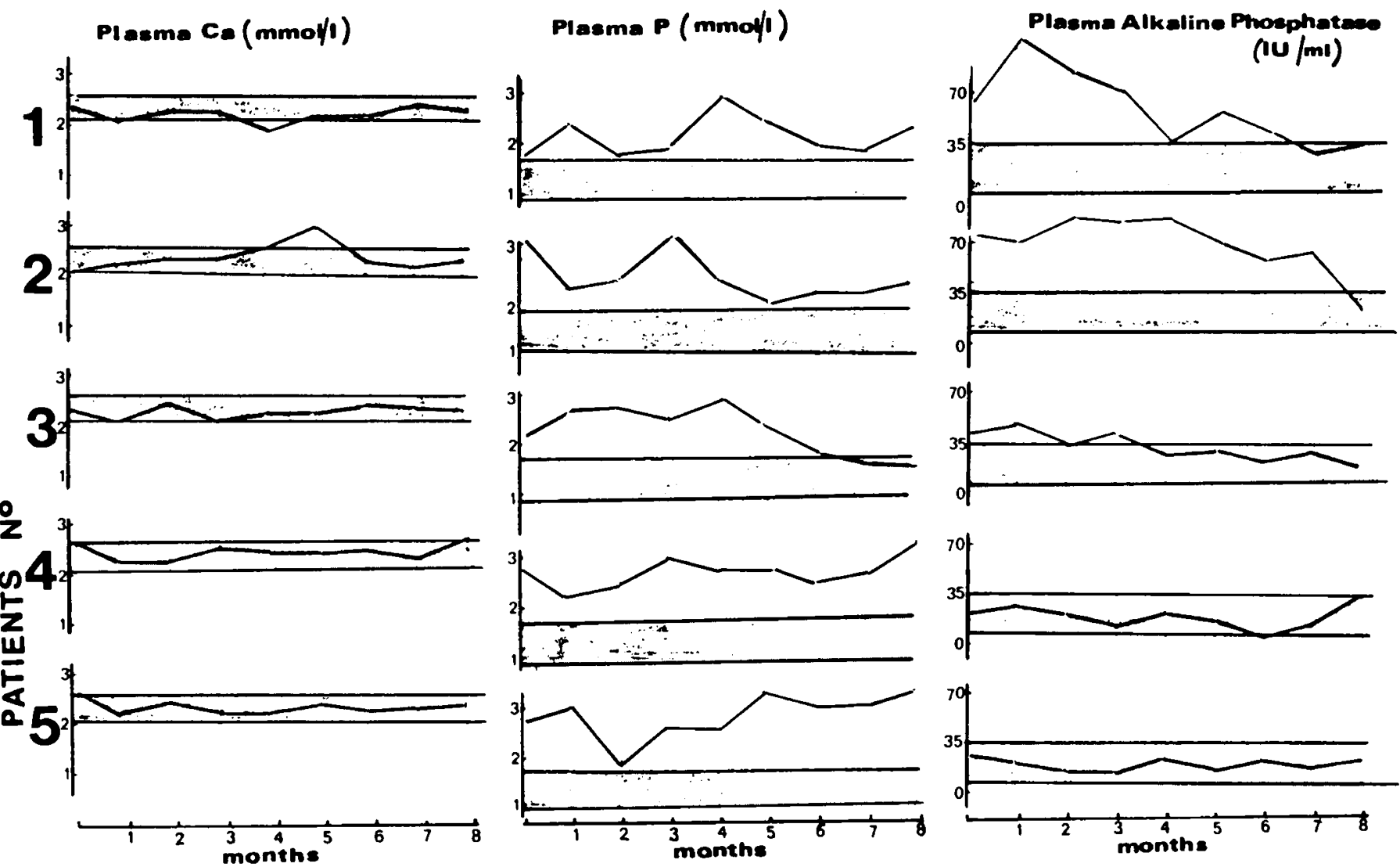

Fig. 1. Effects of $25 \mathrm{OH}$ cholecalciferol on plasma calcium, phosphorus, and alkaline phosphatase; shaded areas represent normal ranges

rapidly synthetised by osteoblasts and the osteoblastic appositional rate in woven zones is about twice normal as shown in Paget's disease of bone (14), fracture callus, or osteosclerotic metastases.

\section{CONCLUSION}

Despite the small number of patients studied, these results suggest the importance of limiting the prescription of 25 OH D3 to children suffering from renal osteodystrophy only after having assessed unequivocally an osteomalacic component by histodynamical criteria.

Secondary hyperparathyroidism appears not to be improved with moderate doses of $25 \mathrm{OH} \mathrm{D} 3$ in the absence of adequate serum phosphorus control.

\section{REFERENCES AND NOTES}

I. Babson A. L., Greeley, S. I., Coleman, C. M., and Philips, G. E.: The use of phenolphtalein monophosphate as a substrate for serum alkaline phosphate. Clin. Chem., 12: 482 (1966).

2. Bernheim, J., and David L.: Le dosage radioimmunologique de la parathormone. Lyon Med. 232: 429 (1974).

3. Bordier, P. J., Marie, P. J., and Arnaud, C. D.: Evolution of renal osteodystrophy: correlation of bone histomorphometry and serum mineral and immunoreactive parathyroid hormone values before and after treatment with calcium carbonate or 25-hydroxycholecalciferol. Kidney Int. 2: S102 (1975).

4 Bordier, P. J., Tunchot, S., Eastwood. J. B., Fournier, A., and De Wardener, H. E.: Lack of histological evidence of vitamin $D$ abnormality in the bones of anephric patients. Clin. Sci. Mol. Med., 44: 33 (1973).

5. Conaway, H. H., and Anast, C. S.: Double antibody radioimmunoassay for parathyroid hormone. J. Lab. Clin. Med., 83: 129 (1974).

6. Eastwood, J. B., Harris, E., Stamp, T. C. B., and De Wardener, H. E.: Bone mineralisation and plasma $25 \mathrm{OH}$ vitamine $\mathrm{D}$ in chronic renal failure. Lancet, 2: 1209 (1976).

7. Eastwood. J. B., Stamp. T. C. B., De Wardener, H. E., Bordier, P. J., and Arnaud, C. D.: The effect of 25 Hydroxy vitamine D3 in the osteomalacia of chronic renal failure. Clin. Sci. Mol. Med., 52: 499 (1977).

8. Ferran. J. L., Luciani, J. C., Meunier, P., Dumas, R.: Osteodystrophie renale de l'enfant: confrontations radio-histologiques. J. Radiol. Electrol., 58: 173 (1977).

9. Fournier, A. F., Bordier, P. J., Gueris, J., Chanard, J., Marie, P., Ferriere, C., Osario, M., Debrossian. J., and De Luca, H. F.: 1 a-hydroxycholecalciferol and 25 hydroxycholecalciferol in renal bone disease. Proc. Eur. Dial. Transplant Assoc.. 12: 227 (1975).

10. Frost, H. M.: Tetracycline-based histological analysis of bone remodeling. Calc. Tiss. Res. 3: 211 (1969).

11. Greulich. W. W., and Pyle, S. I.: Radiographic Atlas of Skeletal Development of the Hand and Wrist. 2nd Edition (Stanford University Press, Stanford 1959).

12. Luciani, J. C., Ferran, J. L., Dumas, M. L., Meunier, P., and Dumas, R.: Osteodystrophie de l'enfant hemodialyse (6 observations). Nouv. Presse Med. 6: 3615 (1977).

13. Meunier, P., Edouard, C., Bressot, C., Vallat, J. N., Courpron, P., and Zech, P.: Histomorphométrie osseuse dans l'insuffisance renale aigue et chronique. Les critères de définition de l'ostéomalacie. J. Urol. Nephrol., 81: 931 (1975).

14. Meunier, P. J.: Disturbances in morphology and dynamics of the remodeling process in pagetic bone. In: I. Maclntyre: Proceedings of an International Workshop. Human Calcitonin and Paget's disease. 78-89 (Hans Huber Publishers, Bern, 1977).

15. Nielsen, H. E., Melsen, F., Christensen, M. S., Hansen, H. E., Rodbro, P., and Johannsen, A.: I $\alpha$ hydroxycholecalciferol treatment of long-term hemodialyzed patients. Effects on mineral metabolism, bone mineral content and bone morphometry. Clin. Nephrol., 8: 429 (1977).

16. Nielsen, H. E., Melsen, F., Lund, B., Sorensen, O. H., and Christensen, M. S. Serum 25-hydroxycholecalciferol and renal osteodystrophy. Lancet l: 754 (1977).

17. Pors Nielsen, S., Binderup, E., Godtfredsen, W. O., Jensen, H., and Ladefoged, J.: I a hydroxycholecalciferol. Long-term treatment of patients with uraemic osteodystrophy. Nephron.. 16: 359 (1976)

18. Preece, M. A., O'Riordan, J. L. H., Lawson, D. E. M., and Kodiceck, E.: A competitive protein binding assay for $25 \mathrm{OH}$ cholecalciferol and $25 \mathrm{OH}$ ergocalciferol in serum. Clin. Chim. Acta, 54: 235 (1974).

19. Teitelbaum, S. L., Bone, J. M., Stein, P. M., Gilden, J. J., Bates, M., Boisseau, V. C. and Avioli, L. V.: Calcifediol in chronic renal insufficiency. Skeletal response. J.A.M.A., 235: 164 (1976).

20. Wezeman, F. H.: 25 hydroxyvitamin D3: autoradiographic evidence of sites of action in epiphyseal cartilage and bone. Science. 194: 1069 (1976).

21. Witmer, G., Margolis, A., Fontaine, O., Fritsch, J., Lenoir, G., Broyer, M., and Balsan, S.: Effects of 25 Hydroxycholecalciferol on bone lesions of children with terminal renal failure. Kidney Int., 10: 395 (1976).

22. The authors thank Dr. L. David (Hôpital Debrousse, Lyon, France) for the assay of plasma parthyroid hormone and to Dr. C. Ribot (C.H.U. de Rangueil. Toulouse, France) for measuring plasma 25-hydroxycholecalciferol.

23. Requests for reprints should be addressed to: Dr. J.-C. Luciani. Service de Médecine D-Höpital Saint-Charles-34059 Montpellier cedex (France).

24. Received for publication January 11, 1978.

25. Accepted for publication November 7, 1978. 